\title{
Effects of simultaneous interference upon free recall learning and retention
}

\author{
GILLES 0. EINSTEIN \\ University of Colorado, Boulder, Colorado 80809
}

\begin{abstract}
Learning and retention were examined under varying amounts of intratask interference during learning. All subjects were required to learn the same list of auditorily presented words while concurrently processing a visually presented interfering list. Differential amounts of interference were produced by varying the relatedness of the interfering list to the learning list. The common learning list consisted of four general categories that also contained members of more restricted subcategories. Some subjects were instructed about the existence and names of the subcategories. The results showed that interference lengthened learning but, in some cases, facilitated retention relative to control groups. Restricted category knowledge facilitated learning but had no effect on retention. There were no significant retention differences after 1 week, but after 5 weeks retention performance was significantly better for groups that learned under related interference conditions. The results were interpreted in terms of more elaborate encoding of the items in the high intratask interference conditions.
\end{abstract}

Intratask interference present at the time of learning has repeatedly been shown to produce superior performance on subsequent retention or transfer tasks. The widespread generality of this result led to Battig's (1972) principle specifying intratask interference as a source of facilitation in transfer and retention. Previous experiments supportive of this principle, however, have typically involved comparisons between different learning lists representing different levels of such variables as intralist similarity (e.g., Pellegrino, 1972). Because such comparisons between different lists inevitably introduce other possible dimensions of difference besides intratask interference, the specific mechanism(s) responsible for subsequent facilitating effects have proved difficult to identify.

In an effort to avoid the aforementioned confounding by providing "intratask" interference from sources extraneous to the actual learning list, the present experiment varied interference during learning by requiring subjects to perform, concurrently, additional processing tasks upon materials varying systematically in their relationship to the words in the actual free recall learning list. Previous research employing totally unrelated

This is Publication No. 66 of the Institute for the Study of Intellectual Behavior, University of Colorado. This paper is based on a thesis submitted by the author in partial fulfillment of the requirements of a Master's degree and was supported by Grant GB34077X from the National Science Foundation. The author is indebted to the chairman of his thesis committee, William F. Battig, for his invaluable comments and support throughout all phases of this study, as well as to Bruce R. Ekstrand and Gregory A. Kimble, members of the thesis committee. Appreciation is also extended to James $W$. Pellegrino and John $H$. Mueller for providing the computer programs used for the organizational analyses and to Colleen Tovani for her assistance throughout with the materials and manuscript preparation. Requests for reprints should be sent to Gilles O. Einstein, Department of Psychology, University of Colorado, Boulder, Colorado 80309. concurrent processing tasks has shown substantial interference with free recall learning (e.g., Baddeley, Scott, Drynan, \& Smith, 1969), with the result that performance on such concurrent processing tasks has become a common measure of "expended processing capacity" required by various aspects of the learning task (e.g., Johnston, Wagstaff, \& Griffith, 1972). None of this research with concurrent processing tasks, however, has examined these effects upon delayed retention or used concurrent tasks varying in similarity to the learning task, which were the primary purposes of the present research.

Previous research has shown more effective types of processing and/or better delayed recall by subjects faced with an interfering interpolated task (Gotz \& Jacoby, 1974). Such results further indicate the potential value of the present technique for specifying what subjects actually do in the presence of such interference that facilitates delayed retention. Among the likely possibilities suggested previously (Battig, 1972) are that intratask interference (1) forces subjects to acquire and/or use more complex learning strategies with consequent deeper processing (Craik \& Lockhart, 1972), (2) makes the learning more resistant to the kinds of subsequent interference that normally would produce forgetting, and/or (3) leads subjects to find and use more rules or strategies that may be available in the material to be learned. In an attempt to evaluate these possible interpretations, the present design included systematic variations both in type of processing required by the concurrent task and in the similarity relationship(s) between the materials contained in the concurrent processing and learning tasks.

The present concurrent processing tasks all required subjects to press one of four buttons corresponding to the correct one of four alternatives for each of a series of words presented visually during the aural presentation 
of the free recall learning list. The latter 24-word list, which was identical for all subjects, consisted of six words from each of four conceptual categories, which were learned to a high criterion and tested for retention after 1 week and again after 5 weeks. Five experimental groups differed as to type of concurrent processing task required on each trial during presentation of the aural learning list, and/or type of relationship between the words in the two lists, as summarized below (and described more fully in Table 1 and the Method section).

Two unrelated processing groups were required to process a set of 24 words representing four different categories from those constituting the learning list. The orthographic unrelated processing task required responding with the one of four alternative letters which appeared in each word, while the semantic unrelated processing task required selection of the one of four conceptual category labels which applied to each word. Since the latter semantic task presumably required greater "depth of processing" (Craik \& Lockhart, 1972), these two unrelated processing tasks provide a potential evaluation of whether deeper semantic processing per se in the concurrent interfering task is sufficient to produce facilitation of delayed retention.

To evaluate the importance of relationships between materials in the processing and learning tasks, the foregoing semantic processing task was also performed by each of three related processing groups, which differed from the semantic unrelated processing group only in that the conceptual categories of the words in the processing task were the same as those in the learning list. As illustrated in Table 1, the words in the learning list all represented restricted subcategories within their broader conceptual categories (green vegetables, ground insects, wind musical instruments, and individual sports). For the same related processing group, the 24 interfering words to be processed included equal numbers of words which were and were not consistent with the aforementioned subcategories, thereby preventing usage of subcategory knowledge to distinguish between the processing and learning lists. For the remaining two different related processing groups, however, none of the 24 words in the processing list belonged to the same subcategory as the words in the learning list. Thus, in addition to determining the role of relatedness between the learning and processing tasks in learning and delayed retention, comparisons involving the same and different related processing groups also permitted the evaluation of possible usage of the subcategory "rule" within the different related processing groups to overcome the interference between the learning and processing lists.

Because of the potential importance of subjects' knowledge about the subcategories characterizing the learning as contrasted with the processing list, the instructed different related processing group was ex-

Table 1

Learning and Interfering Lists

\begin{tabular}{|c|c|c|c|}
\hline Learning List & $\begin{array}{c}\text { Unrelated } \\
\text { Interfering List }\end{array}$ & $\begin{array}{l}\text { Different Related } \\
\text { Interfering List }\end{array}$ & $\begin{array}{l}\text { Same Related } \\
\text { Interfering List }\end{array}$ \\
\hline All Groups & $\begin{array}{l}\text { Orthographic and Semantic } \\
\text { Unrelated Processing Groups }\end{array}$ & $\begin{array}{c}\text { Instructed and } \\
\text { Noninstructed Different } \\
\text { Related Processing Groups }\end{array}$ & $\begin{array}{l}\text { Same Related } \\
\text { Processing Group }\end{array}$ \\
\hline $\begin{array}{l}\text { Spinach } \\
\text { Lettuce } \\
\text { Asparagus } \\
\text { Celery } \\
\text { Lima Bean } \\
\text { Cucumber }\end{array}$ & $\begin{array}{l}\text { Apartment } \\
\text { Hotel } \\
\text { Igloo } \\
\text { Castle } \\
\text { Cabin } \\
\text { Duplex }\end{array}$ & $\begin{array}{l}\text { Tomato } \\
\text { Carrot } \\
\text { Beet } \\
\text { Cauliflower } \\
\text { Onion } \\
\text { Radish }\end{array}$ & $\begin{array}{l}\text { Pea } \\
\text { Stringbean } \\
\text { Broccoli } \\
\text { Cauliflower } \\
\text { Onion } \\
\text { Radish }\end{array}$ \\
\hline $\begin{array}{l}\text { Ant } \\
\text { Grasshopper } \\
\text { Beetle } \\
\text { Cockroach } \\
\text { Termite } \\
\text { Caterpillar }\end{array}$ & $\begin{array}{l}\text { Bus } \\
\text { Motorcycle } \\
\text { Streetcar } \\
\text { Jeep } \\
\text { Bicycle } \\
\text { Taxi }\end{array}$ & $\begin{array}{l}\text { Moth } \\
\text { Bee } \\
\text { Dragonfly } \\
\text { Buttėrfly } \\
\text { Mosquito } \\
\text { Hornet }\end{array}$ & $\begin{array}{l}\text { Centipede } \\
\text { Roach } \\
\text { Spider } \\
\text { Butterfly } \\
\text { Mosquito } \\
\text { Hornet }\end{array}$ \\
\hline $\begin{array}{l}\text { Trumpet } \\
\text { Flute } \\
\text { Saxophone } \\
\text { Tuba } \\
\text { Oboe } \\
\text { Harmonica }\end{array}$ & $\begin{array}{l}\text { Copper } \\
\text { Zinc } \\
\text { Nickel } \\
\text { Uranium } \\
\text { Platinum } \\
\text { Steel }\end{array}$ & $\begin{array}{l}\text { Cello } \\
\text { Violin } \\
\text { Banjo } \\
\text { Piano } \\
\text { Drum } \\
\text { Xylophone }\end{array}$ & $\begin{array}{l}\text { Clarinet } \\
\text { Trombone } \\
\text { French Horn } \\
\text { Piano } \\
\text { Drum } \\
\text { Xylophone }\end{array}$ \\
\hline $\begin{array}{l}\text { Tennis } \\
\text { Archery } \\
\text { Bowling } \\
\text { Wrestling } \\
\text { Fencing } \\
\text { Handball }\end{array}$ & $\begin{array}{l}\text { Burglary } \\
\text { Treason } \\
\text { Forgery } \\
\text { Blackmail } \\
\text { Murder } \\
\text { Arson }\end{array}$ & $\begin{array}{l}\text { Rugby } \\
\text { Volleyball } \\
\text { Soccer } \\
\text { Softball } \\
\text { Hockey } \\
\text { Lacrosse }\end{array}$ & $\begin{array}{l}\text { Boxing } \\
\text { Golf } \\
\text { Skiing } \\
\text { Softball } \\
\text { Hockey } \\
\text { Lacrosse }\end{array}$ \\
\hline
\end{tabular}


plicitly informed about the subcategory labels characterizing the learning and processing lists. The second noninstructed different related processing group, however, was given no such instructions. To evaluate the effect of these instructions about the subcategories per se, two additional instructed and noninstructed control groups were also included, neither of which received any additional processing tasks along with their learning list. The absence of any extraneous interference within these control groups thus provided appropriate baselines for assessing the effects of the several related and unrelated processing tasks upon learning and delayed retention.

\section{METHOD}

\section{Groups and Processing Tasks}

All subjects in the five experimental groups and two control groups were required to learn the same aurally presented 24 item list. As shown in Table 1, the learning list for all groups was composed of six items from each of four taxonomic categories (vegetables, insects, musical instruments, and sports). All 24 words were also consistent with the more specific subcategory labels of green vegetables, ground insects, wind musical instruments, and nonteam sports.

In addition to learning this list, subjects in each of the five experimental groups were also required to process simultaneously one of three different visually presented interfering lists, each also containing 24 items representing four categories of six items each (see Table 1). As described below, the unrelated interference list was processed both by orthographic and semantic unrelated processing groups, while both instructed and noninstructed groups processed the different related interference list, and the fifth experimental group alone processed the same related interference list.

As shown in Table 1, three interfering lists varied according to their taxonomic similarity to the learning list. The totally unrelated interference list was constructed by using categories completely different from those in the learning list (i.e., dwellings, vehicles, metals, and crimes; see Table 1). The other two interference lists were semantically related to the learning list, both using different words from the same four categories as the learning list. As shown in Table 1, the different related interference list was distinguishable from the learning list on the basis of its subcategories (e.g., nongreen vegetables, nonground insects, nonwind musical instruments, and nonindividual sports). The same related interference list, however, was not distinguishable from the learning list on the basis of subcategories, since it contained an equal number of subcategory consistent and inconsistent items in each category (see Table 1).

All subjects were given standard free recall instructions concerning the learning list, being told also that the list could be categorized and that it might or might not be useful for them to look for subcategories within the learning list (an extralist example was provided to demonstrate the latter point). In addition, the instructed different related processing group and instructed control group both were given, immediately after the first recall trial, the exact subcategory labels for the learning list (as well as for the interference list in the former group) and a card on which the specific subcategories were listed.

Depending on the experimental condition, subjects were forced to process the list items either orthographically or semantically. The processing task used for the orthographic unrelated processing group required that subjects select the one of four letters which appeared in each interfering list item. The semantic processing task used for the other four experimental groups required subjects to choose the one of four categories to which the interfering list item belonged. As designated in Table 1, the semantic unrelated processing group processed the unrelated list used also for the orthographic unrelated processing group. The same related processing group processed the related list which overlapped with the learning list in subcategory membership. The remaining two different related processing groups both processed the interfering list with different subcategory membership from the learning list, one group with and the other without explicit instructions about these subcategories. The final two instructed and noninstructed control groups also differed only in instructions, but both differed from the experimental groups in being given no interfering task of any kind. The last four groups could be examined factorially in a 2 by 2 analysis of variance, which was used repeatedly and will be hereafter described as the instructions by related interference analysis.

\section{Materials and Apparatus}

The six items from each of the four categories in the 24item learning list had a mean category ranking of 12.00 in the Battig and Montague (1969) norms and were equal to the items in the three interfering lists in mean category ranking. Four systematic randomizations of the common learning list order and of each interfering list order were constructed so that one member of each category was represented within every block of four items and each item appeared in each quadrant of the list over the four list orders. For the first trial, each of the four learning list orders was paired with each of the four interfering list orders once, forming 16 different orders in each condition. Although the first combination of learning and interfering lists was unique to every subject in each condition, the sequences over trials of both the interfering and learning list orders were the same for all subjects.

All interfering list items were typed in capitals on the top half of individual $2 \times 2$ in. slides. For the semantic processing groups, four lowercase category labels (including one for each category in the interference list) appeared below each interfering list item. Four uppercase letters were typed below each interfering list item for the orthographic unrelated processing group, using six different letters to construct the required four alternatives, so that only one of the letters was correct for each interfering list item. The four alternatives in all groups were situated diagonally from upper left to lower right on the bottom half of each slide, below the word to be processed. These alternative positions on the slide corresponded to four buttons, also situated from left to right, on a response box which subjects had in front of them. Subjects were instructed to press the button on the response box which corresponded to the correct alternative for each interfering list item. In every interference group, all possible combinations of the alternatives appeared equally often and each alternative, as well as each alternative position, was correct equally often within each block of 24 items. Also, the same four alternatives always appeared with the same words across trials, and the same button position was never correct more than twice in succession.

\section{Procedure}

All items in the learning list were auditorily presented at a 2.5 -sec rate using a SONY stereo tape recorder. The visually presented interfering items were presented concurrently with the learning list and were subject paced. After the presentation of the learning list, the slide projector was immediately turned off, and subjects were given 2 min for recall of their auditorily presented words. Subjects in the experimental groups were given two exampies to illustrate the interference task. At the beginning of every trial, they were told that their interfering task was as important to the experiment as learning the auditorily presented list. 
In order to emphasize category learning, learning trials for all subjects were terminated immediately following the recall trial on which five of the six items from each of the four categories were correctly recalled. When the learning session was over, subjects were asked to return the following week for a totally different experiment.

The 1-week retention session began with preliminary general instructions, after which a test booklet was given containing all further instructions and tests. Subjects were required to write, in any order, as many of the items from the auditory list as they could in a 2 -min period, followed by an unlimited amount of time in which to recall as many additional items as possible.

The free recall tests were followed by additional measures to determine the particular category labels used by each subject. The measures included asking subjects to group a totally new list of items into clusters consistent with the way they processed the original list and to label the clusters. All of these new items were either consistent or inconsistent with the specific subcategory labels in the original learning list. All subjects were next presented with the original learning list and simply asked to write down the category label(s) they used to process each item. This was followed by a self-paced test in which subjects were to write down all the items they could remember from their interfering list. Finally, subjects were asked to write any comments they had about the experiment, including any strategies they used to acquire and retain the learning list.

Between 25 and 35 days after the retention session, the experimenter attempted to reach each subject by telephone. Those subjects contacted (between $44 \%$ and $69 \%$ in each group, see Table 3 ) were simply asked to recall orally as many list items as they could in an unlimited amount of time. All during this retention measurement, the experimenter was "blind" as to what group the subject was in.

\section{Subjects}

The 16 subjects in each of the seven conditions were University of Colorado introductory psychology students fulfilling a course requirement through their participation, who were tested individually during the learning and retention phases of the experiment.

\section{RESULTS}

\section{Acquisition}

Only the results of the errors to criterion measure will be described, since both errors and trials to criterion yielded identical results (see Table 2). There were highly significant $[F(6,105)=8.76, p<.001]$ overall differences between groups. A planned comparison showed that $85 \%$ of this between-groups variance was attributable to the reliably $[F(1,105)=44.64, p<.001]$ fewer errors by the two control groups compared to the five groups which learned under interfering conditions. Further comparisons revealed that the instructed different related processing group learned faster than the other four interference groups $[F(1,105)=5.59, \mathrm{p}<.025]$ but that the four noninstructed unrelated and related processing groups did not differ from each other $(p>.20)$. The closely comparable performance by the same and noninstructed different related processing groups indicates that subjects in the latter group were not recognizing and/or using the experimenter-defined subcategory distinction between their learning and interfering lists.

Only the interference variable was significant $[F(1,60)=206.96, p<.001]$ when an instructions by related interference analysis of variance was performed on the number of words correctly recalled on the first trial prior to the instructions, showing that there were no sampling differences between the instructed and noninstructed groups. Both interference $[F(1,60)=47.08, p<.001]$ and instructions $[F(1,60)=$ $7.12, \mathrm{p}<.01]$ were shown to be reliable and potent learning variables when this analysis was performed on errors to criterion. Further analyses revealed that the instructional manipulation was effective immediately on the initial trial following the instructions.

\section{Processing of Interfering Items}

The number of interfering items processed was analyzed as another measure of the interfering effect of the distractor list, since the difficulty of the interfering tasks should have been dependent upon their interaction with the auditorily presented list. As can be seen in Table 2, all groups processed nearly the same number of visually presented items on each trial, except for the significantly greater number of items processed by the

Table 2

Means and Standard Deviations for Control and Experimental Groups

\begin{tabular}{|c|c|c|c|c|c|c|c|c|}
\hline & & \multicolumn{2}{|c|}{ Unrelated Processing } & \multicolumn{2}{|c|}{$\begin{array}{l}\text { Different } \\
\text { Related Processing }\end{array}$} & \multirow[b]{2}{*}{$\begin{array}{c}\text { Same Related } \\
\text { Processing }\end{array}$} & \multicolumn{2}{|c|}{ Control } \\
\hline & & $\begin{array}{l}\text { Ortho- } \\
\text { graphic }\end{array}$ & Semantic & $\begin{array}{c}\text { Non- } \\
\text { instructed }\end{array}$ & $\begin{array}{c}\text { In- } \\
\text { structed }\end{array}$ & & $\begin{array}{c}\text { Non- } \\
\text { instructed }\end{array}$ & $\underset{\text { structed }}{\text { In- }}$ \\
\hline Errors to criterion & $\begin{array}{l}\text { Mean } \\
\text { SD }\end{array}$ & $\begin{array}{l}81.4 \\
37.8\end{array}$ & $\begin{array}{l}99.2 \\
78.4\end{array}$ & $\begin{array}{r}107.5 \\
53.5\end{array}$ & $\begin{array}{l}71.7 \\
39.8\end{array}$ & $\begin{array}{r}105.4 \\
48.5\end{array}$ & $\begin{array}{l}34.2 \\
22.9\end{array}$ & $\begin{array}{l}22.3 \\
11.9\end{array}$ \\
\hline Trials to criterion & $\begin{array}{l}\text { Mean } \\
\text { SD }\end{array}$ & $\begin{array}{l}9.4 \\
4.0\end{array}$ & $\begin{array}{r}10.6 \\
6.2\end{array}$ & $\begin{array}{r}11.6 \\
4.4\end{array}$ & $\begin{array}{l}7.9 \\
4.2\end{array}$ & $\begin{array}{r}11.3 \\
4.4\end{array}$ & $\begin{array}{l}5.4 \\
3.1\end{array}$ & $\begin{array}{l}3.7 \\
1.9\end{array}$ \\
\hline $\begin{array}{l}\text { Number of interfering list } \\
\text { items processed per trial }\end{array}$ & $\begin{array}{l}\text { Mean } \\
\text { SD }\end{array}$ & $\begin{array}{r}20.9 \\
3.1\end{array}$ & $\begin{array}{r}27.1 \\
3.3\end{array}$ & $\begin{array}{r}21.5 \\
2.0\end{array}$ & $\begin{array}{r}21.9 \\
2.8\end{array}$ & $\begin{array}{r}21.4 \\
3.0\end{array}$ & & \\
\hline $\begin{array}{l}\text { Intrusions as a percentage } \\
\text { of total errors to criterion }\end{array}$ & $\begin{array}{l}\text { Mean } \\
\text { SD }\end{array}$ & $\begin{array}{l}.05 \\
.06\end{array}$ & $\begin{array}{l}.02 \\
.02\end{array}$ & $\begin{array}{l}.17 \\
.13\end{array}$ & $\begin{array}{l}.09 \\
.13\end{array}$ & $\begin{array}{l}.15 \\
.12\end{array}$ & $\begin{array}{l}.02 \\
.03\end{array}$ & $\begin{array}{l}.06 \\
.14\end{array}$ \\
\hline Correlations* & & .60 & .33 & -.12 & .32 & .30 & & \\
\hline
\end{tabular}

*Between trials to criterion and number of interfering list items processed 
semantic unrelated processing group $[F(1,75)=4.85$, $\mathrm{p}<.05$ ], indicating that interference is reduced when the interfering and learning tasks are urrelated to each other. Interference was not reduced in the case where the two lists were composed of the same categories but were distinguishable in terms of their subcategories (instructed and noninstructed different related processing groups), even when subjects were aware of this distinction. That the orthographic unrelated processing group did not process as many items as the semantic unrelated processing group probably reflects the greater difficulty of the present orthographic processing task.

Correlations between trials to criterion and number of interfering items processed were uniformly low and nonsignificant in all four of the semantic processing groups (see last row of Table 2). Only in the orthographic unrelated processing group was there any strong indication that subjects were learning the auditory list at the expense of the interfering list, although even here this relationship accounted for only $36 \%$ of the variance.

\section{Serial Position Effects}

As shown in Figure 1, the first-trial serial position curves showed a significant Groups by Serial Position interaction $[F(66,1155)=1.64, \mathrm{p}<.01]$. attributable to the sharp contrast between the control and experimental groups. Because Figure 1 indicates differential recency, as compared to primacy, effects as the locus of the experimental-control differences, further analyses were based only on the first and last two items. These showed recency recall for the pooled experimental groups to be not only significantly higher than primacy recall $[\mathrm{F}(1,75)=127.98, \mathrm{p}<.001]$ but also above recency recall by the control groups $[F(1,105)=4.67$, $\mathrm{p}<.05]$, as is typical for naive subjects on the first trial under such successive presentation conditions

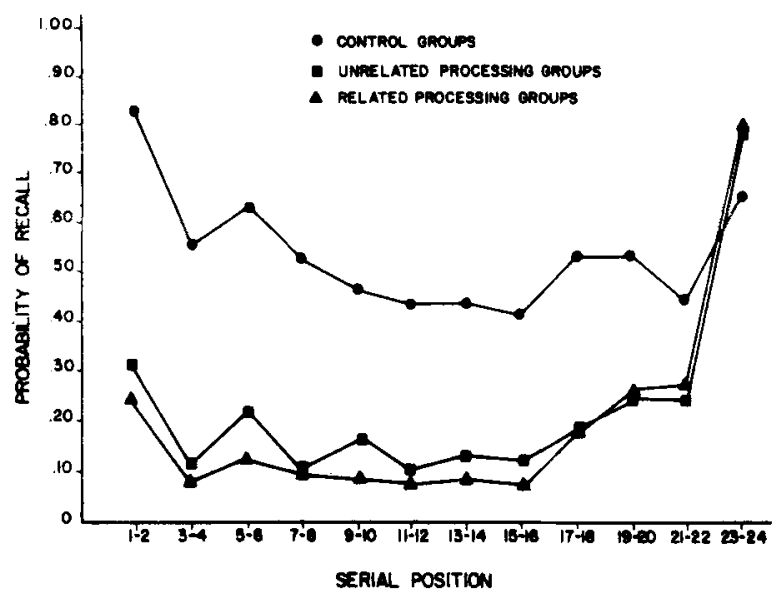

Figure 1. First-trial serial position functions of recall for the two control groups, two unrelated processing groups, and three related processing groups. (see Battig, 1975). It appears that subjects required to concurrently process an interfering list had difficulty in getting many items into a more permanent memory storage, and thus became more dependent on recency strategies limited to the last two items.

\section{Organizational Analysis}

Both clustering (ARC: Roenker, Thompson, \& Brown, 1971) and subjective organization $\left(\mathrm{ARC}_{\alpha / \mathrm{x}}^{\prime}\right.$ : Pellegrino, 1971) measures were computed for each subject to determine if the presence of interference forced usage of more consistent and powerful types of organizational strategies. Due to wide variations both within and between groups in trials to criterion and number of words recalled on the early trials, both measures are reported only for the last trial for each subject.

All groups exhibited reliable taxonomic clustering $[F(1,105)=16.91, p<.001]$ and subjective organization $[F(1,105)=236.91, p<.001]$. The only significant group differences reflected more clustering $[F(1,105)=3.97, p<.05]$ in the three related process. ing groups $(\overline{\mathrm{X}}=.85)$ than in the other four groups $(\bar{X}=.76)$, and more unidirectional organizational units of Size 3 by the related processing groups $(\overline{\mathrm{X}}=.06)$ than by the control groups $(\overline{\mathrm{X}}=.04)[\mathrm{F}(1,60)=5.83$, $\mathrm{p}<.025]$.

\section{Retention of the Learning List}

As shown in Table 3, retention was measured as the percentage of originally learned items retained for two of the three retention measures (total items and items per category) and as number of categories retained for the category retention measure. Percentage measures were used because mean recall on the criterion trial was significantly greater $[F(1,105)=9.84, p<.01]$ for the two control groups (21.91) than for the five experimental groups (21.21). That any delayed retention results were not contaminated by differences on the criterion trial is indicated by (1) the relatively small criterion differences, (2) highly irregular and generally low within-group correlations between criterion trial recall and 1 -week retention (median $r=.23$ ), and (3) the closely comparable patterns of group differences for absolute number of items recalled as compared to the percentage retention measures shown in Table 3.

Analyses including both the 2-min and unlimited time 1 -week retention tests revealed only a significant improvement from the former to the latter $[F(1,105)=$ $101.88, p<.001]$ and reliably more categories retained by the three related processing groups than by the other four groups $[F(1,105)=6.59, p<.025]$. Unequal-n analyses were performed on the 5-week retention, since only $44 \%$ to $69 \%$ of the subjects in each group were contacted (see Table 3). Although the main effect of groups was not significant, both mean recall percentages $[F(1,60)=4.07, p<.05]$ and percentage of items 
Table 3

Means and Standard Deviations for Percentage of Items, Items Per Category, and Number of Categories Retained for all Seven Groups on the Three Retention Tests

\begin{tabular}{|c|c|c|c|c|c|c|c|c|c|}
\hline & & & \multicolumn{2}{|c|}{ Unrelated Processing } & \multicolumn{2}{|c|}{$\begin{array}{c}\text { Different } \\
\text { Related Processing }\end{array}$} & \multirow[b]{2}{*}{$\begin{array}{c}\text { Same Related } \\
\text { Processing }\end{array}$} & \multicolumn{2}{|c|}{ Control } \\
\hline & & & $\begin{array}{l}\text { Ortho- } \\
\text { graphic }\end{array}$ & Semantic & $\begin{array}{c}\text { Nonin- } \\
\text { structed }\end{array}$ & $\begin{array}{c}\text { In- } \\
\text { structed }\end{array}$ & & $\begin{array}{l}\text { Nonin- } \\
\text { structed }\end{array}$ & $\begin{array}{c}\text { In- } \\
\text { structed }\end{array}$ \\
\hline \multirow{3}{*}{ Total items } & Timed & $\begin{array}{l}\text { Mean } \\
\text { SD }\end{array}$ & $\begin{array}{l}.64 \\
.21\end{array}$ & $\begin{array}{l}.65 \\
.17\end{array}$ & $\begin{array}{l}.64 \\
.16\end{array}$ & $\begin{array}{l}.71 \\
.12\end{array}$ & $\begin{array}{l}.67 \\
.15\end{array}$ & $\begin{array}{l}.63 \\
.21\end{array}$ & $\begin{array}{l}.64 \\
.14\end{array}$ \\
\hline & Untimed & $\begin{array}{l}\text { Mean } \\
\text { SD }\end{array}$ & $\begin{array}{l}.74 \\
.22\end{array}$ & $\begin{array}{l}.78 \\
.14\end{array}$ & $\begin{array}{l}.77 \\
.17\end{array}$ & $\begin{array}{l}.79 \\
.10\end{array}$ & $\begin{array}{l}.78 \\
.16\end{array}$ & $\begin{array}{l}.71 \\
.21\end{array}$ & $\begin{array}{l}.72 \\
.16\end{array}$ \\
\hline & 5-Week & $\begin{array}{l}\text { Mean } \\
\text { SD }\end{array}$ & $\begin{array}{l}.67 \\
.27\end{array}$ & $\begin{array}{l}.55 \\
.21\end{array}$ & $\begin{array}{l}.72 \\
.23\end{array}$ & $\begin{array}{l}.68 \\
.09\end{array}$ & $\begin{array}{l}.66 \\
.20\end{array}$ & $\begin{array}{l}.52 \\
.17\end{array}$ & $\begin{array}{l}.62 \\
.17\end{array}$ \\
\hline \multirow{3}{*}{ Items/category } & Timed & $\begin{array}{l}\text { Mean } \\
\text { SD }\end{array}$ & $\begin{array}{l}.69 \\
.19\end{array}$ & $\begin{array}{l}.73 \\
.13\end{array}$ & $\begin{array}{l}.67 \\
.15\end{array}$ & $\begin{array}{l}.73 \\
.11\end{array}$ & $\begin{array}{l}.68 \\
.14\end{array}$ & $\begin{array}{l}.66 \\
.17\end{array}$ & $\begin{array}{l}.71 \\
.10\end{array}$ \\
\hline & Untimed & $\begin{array}{l}\text { Mean } \\
\text { SD }\end{array}$ & $\begin{array}{l}.76 \\
.20\end{array}$ & $\begin{array}{l}.81 \\
.12\end{array}$ & $\begin{array}{l}.78 \\
.16\end{array}$ & $\begin{array}{l}.80 \\
.10\end{array}$ & $\begin{array}{l}.78 \\
.16\end{array}$ & $\begin{array}{l}.72 \\
.18\end{array}$ & $\begin{array}{l}.78 \\
.11\end{array}$ \\
\hline & 5-Week & $\begin{array}{l}\text { Mean } \\
\text { SD }\end{array}$ & $\begin{array}{l}.71 \\
.23\end{array}$ & $\begin{array}{l}.60 \\
.15\end{array}$ & $\begin{array}{l}.74 \\
.20\end{array}$ & $\begin{array}{l}.68 \\
.10\end{array}$ & $\begin{array}{l}.68 \\
.18\end{array}$ & $\begin{array}{l}.56 \\
.14\end{array}$ & $\begin{array}{l}.63 \\
.18\end{array}$ \\
\hline \multirow{3}{*}{$\mathrm{N}$ of categories } & Timed & $\begin{array}{l}\text { Mean } \\
\mathrm{SD}\end{array}$ & $\begin{array}{r}3.75 \\
.45\end{array}$ & $\begin{array}{r}3.56 \\
.51\end{array}$ & $\begin{array}{r}3.81 \\
.40\end{array}$ & $\begin{array}{r}3.94 \\
.25\end{array}$ & $\begin{array}{r}3.94 \\
.25\end{array}$ & $\begin{array}{r}3.75 \\
.45\end{array}$ & $\begin{array}{r}3.56 \\
.51\end{array}$ \\
\hline & Untimed & $\begin{array}{l}\text { Mean } \\
\text { SD }\end{array}$ & $\begin{array}{r}3.88 \\
.34\end{array}$ & $\begin{array}{r}3.81 \\
.40\end{array}$ & $\begin{array}{r}3.94 \\
.25\end{array}$ & $\begin{array}{l}4.00 \\
0.00\end{array}$ & $\begin{array}{l}4.00 \\
0.00\end{array}$ & $\begin{array}{r}3.88 \\
.34\end{array}$ & $\begin{array}{r}3.75 \\
.45\end{array}$ \\
\hline & 5-Week & $\begin{array}{l}\text { Mean } \\
\text { SD }\end{array}$ & $\begin{array}{r}3.67 \\
.71\end{array}$ & $\begin{array}{r}3.55 \\
.69\end{array}$ & $\begin{array}{r}3.86 \\
.38\end{array}$ & $\begin{array}{l}4.00 \\
0.00\end{array}$ & $\begin{array}{r}3.89 \\
.33\end{array}$ & $\begin{array}{r}3.70 \\
.71\end{array}$ & $\begin{array}{l}4.00 \\
0.00\end{array}$ \\
\hline \multicolumn{3}{|c|}{$\mathrm{N}$ of subjects contacted at 5 weeks } & 9 & 11 & 7 & 11 & 9 & 10 & 10 \\
\hline
\end{tabular}

recalled per category $[F(1,60)=4.91, p<.05]$ were significantly greater for the three related processing groups than for the two control groups. For subjects participating in the 5-week retention test, 1 - and 5-week retentions were substantially correlated $[\mathrm{r}(64)=.60$, $p<.001]$, and in none of the critical groups did mean 1-week retention of those subjects contacted after 5 weeks differ from their overall group mean by more than $2 \%$, both of which argue against sampling biases as affecting 5-week retention. Only the orthographic unrelated processing group showed a sizable 8\% 1-week retention difference between subjects contacted for 5 -week retention and their overall group mean, which may account for their relatively high 5-week retention shown in Table 3. In addition, retention was shown not to be positively correlated with degree of exposure to the list items during learning (as indexed by trials to criterion) in any of the groups (all $r s \leqslant .17$ ).

\section{Intrusions and Subcategory Usage}

To determine the extent and type of influence of the interfering tasks upon learning, retention, and the way in which items were being categorized, intrusions as well as several subject-rated measures were analyzed.

All analyses of intrusions during learning were calculated as a percentage of total errors to criterion (excluding the first trial) since there was a reliable correlation $(p<.05)$ between these two factors. As shown in Table 2, the significance of the relationship between the materials used in the interfering and learn- ing lists was reflected in the reliably $[\mathrm{F}(6,105)=5.98$, $p<.001]$ greater number of intrusions in the three related processing groups relative to the two control and two unrelated processing conditions, which did not differ from each other. In addition, there were fewer intrusions $[F(1,105)=4.95, p<.05]$ in the instructed different related processing group than in the other two related processing groups. No group differences were found in total retention intrusions. It should also be noted that $34 \%$ of the subjects in the related processing conditions and $31 \%$ of the subjects in the other four groups reported using even more specific types of learning labels than the conceptual subcategories. For example, some subjects categorized celery, lettuce, and cucumber as green vegetables that could go in salads, and spinach, lima bean, and asparagus as vegetables that are cooked; other subjects categorized some of the list items as being enjoyed by themselves or a friend or used first letters, etc.

\section{DISCUSSION}

The present results clearly indicate slower learning with simultaneous interference present during learning. Instructions which enabled subjects to use more restricted category labels were shown to increase learning ease but to have no effect on retention. Retention differences only emerged after 5 weeks, and retention performance was higher for groups that learned under related interference conditions. The value of the 5-week 
retention test may be somewhat limited, because only $56 \%$ of the subjects were included and the telephone procedure provided very little control over how they performed this unpaced recall test. However, any biases produced thereby should have been equivalent across all of the individual groups in the experiment.

Presumably, instructions aided learning by allowing subjects to encode items in a more complete fashion, thereby facilitating processes such as generation and recognition. That high intratask interference conditions produce more usage of rules inherent in the learning material was not demonstrated, however. The lack of subcategory effects on retention may indicate either that subcategory knowledge facilitated the generation of list items only within the actual context of list presentation and/or that many subjects developed other strategies that were equally effective for delayed retention.

Five-week retention was shown to be positively related, not to learning difficulty, but to the similarity between the learning and interfering lists. A possible interpretation of these results is that the similar structure of the interfering list facilitated the long-term retrieval of categories, even though item per category recall may have been interfered with. Arguing against this interpretation, however, are the 5-week retention results showing group differences to be localized in item per category recall.

Another possible interpretation is based on Battig's recent "functional" characterization of intratask interference incorporating activities of the subject which serve to eliminate or change the magnitude of the "nominal" intratask interference as traditionally defined (see also Lauer, Streby, \& Battig, 1976). The similar structure of the learning and interfering tasks seemed to have produced more intratask interference in the three related processing groups, as evidenced by more intrusions therein compared to the other four groups, and fewer interfering items processed relative to the semantic unrelated processing group. Consequently, it may be that subjects in the three related processing groups had to overcome the interference produced by the similarities between specific items across the learning and interfering lists. Such semantic interference could have been reduced by encoding the learning list items in such a way as to be able to distinguish them from interfering list items. If this type of encoding also involved more elaborate or specific types of processing which could also restrict the search set (e.g., green vegetables that $\mathrm{I}$ dislike), the present 5 -week retention results would be consistent with Craik and Tulving (1975).

Also supportive of the above interpretation are the larger unidirectional subjective organization units and greater clustering by related processing groups than by controls at the end of learning. Further analyses revealed that, within each group, subjects who could encode list items more efficiently were likely to produce fewer intrusions and superior retention, while the reverse effect was indicated when different groups were compared. This argues for the different kinds of distractor tasks as the significant determiner of retention facilitation, rather than degree of exposure to the learning list.

It should also be noted that, in most instances where high intratask interference during learning has been shown to facilitate subsequent transfer and/or retention, more complex encoding of the list items was necessary. For example, Pellegrino's (1972) groups learning a highinterference first list (high response formal similarity) showed only half as much forgetting after a transfer task as did subjects learning a low-similarity first list. This indicates that the difficult discrimination of highly similar material by the high intratask interference group may have required more complete encoding of items, thereby making them less susceptible to the interfering effects of a transfer task.

The appearance of retention differences only after 5 weeks in the present experiment has at least three possible interpretations. Since Pellegrino's (1972) high intratask interference groups exhibited superior retention only after a transfer task, the present 1 -week retention tasks (which included new words highly similar to words in the learning list) may have served also as an interfering transfer task. This could have produced more forgetting in those groups which had never overcome interference from similar items during learning. An alternative possibility is that learning under high related intratask interference conditions produces less pronounced forgetting slopes, as also indicated by present research showing imagery effects to decline or reverse as retention interval increases (e.g., Postman \& Burns, 1973).

Finally, Houston's (1969) finding of quite different retention results, depending on whether or not subjects believed the experiment to be finished, may be applicable here. All the present subjects were told to return after 1 week, so rehearsal during this retention interval could have reduced group differences immediately thereafter, but not during the following month after the experiment was allegedly completed. These interpretations suggest the need for further research testing the effects of intratask interference and subjects' awareness of a retention test upon the retention function over time.

\section{REFERENCES}

Baddeley, A. D., Scott, D., Drynan, R., \& Smith, J. C. Short term memory and the limited capacity hypothesis. British Journal of Psychology, 1969, 60, 51-55.

BATTIG, W. F. Intratask interference as a source of facilitation in transfer and retention. In R. F. Thompson \& J. F. Voss (Eds.), Topics in learning and performance. New York: Academic Press, 1972.

Battig, W. F. Within-individual differences in cognitive processes. In R. L. Solso (Ed.), Information processing and cognition: The Loyola symposium. Potomac, Md: Lawrence Erlbaum, 1975.

Battig, W. F., \& Montague, W. E. Category norms for verbal items in 56 categories: A replication and extension 
of the Connecticut category norms. Journal of Experimental Psychology Monograph, 1969, 80, 1-46.

CRAIK. F. I. M., \& LockharT, R. S. Levels of processing: A framework for memory research. Journal of Verbal Learning and Verbal Behavior, 1972, 11, 671-684.

CRAIK, F. I. M., \& Tulving, E. Depth of processing and the retention of words in episodic memory. Journal of Experimental Psychology: General, 1975, 104, 268-294.

Göтz, A., \& JACOBY, L. L. Encoding and retrieval processes in long-term retention. Journal of Experimental Psychology, 1974, 102. 291-297.

Houston, J. P. Proactive inhibition and undetected retention interval rehearsal. Journal of Experimental Psychology, $1969,3,511-514$

Johnston, W. A., Wagstaff, R. R., \& GRiffith, D. Information processing analysis of verbal learning. Journal of Experimental Psychology, 1972, 96, 307-314.

LaUer, P. A., Streby, W., \& Battig, W. F. The effects of alphabetical organization on the acquisition and delayed retention of semantically similar words. Journal of Experimental Psychology: Human Learning and Memory, 1976, 2, 182-189.

Pellegrino, J. W. A general measure of organization in free recall for variable unit size and internal sequential consistency. Behavior Research Methods \& Instrumentation, 1971, 3, 241-246.

Pellegrino, J. W. Effects of intralist response formal similarity upon paired-associate transfer and retroactive inhibition. Journal of Experimental Psychology, 1972, 92, 134-141.

Postman, L., \& Burns, S. Experimental analysis of coding processes. Memory \& Cognition, 1973, 1, 503-507.

Roenker, D. L., Thompson, C. P., \& Brown, S. C. A comparison of measures for the estimation of clustering in free recall. Psychological Bulletin, 1971, 76, 45-48.

(Received for publication December 22, 1975; revision received April 20, 1976.) 